OPEN ACCESS

Vol. 2 No. 1: 9-13

Tahun 2018

Artikel penelitian 圆
Jurreal Alkwatililestari

E-ISSN: 2598-8204

https://ojs.umrah.ac.id/index.php/akuatiklestari

DOI : https://doi.org/10.31629/akuatiklestari.v2i1.931

\title{
Tingkat Kesuburan Perairan di Perairan Kampung Madong, Kelurahan Kampung Bugis, Kota Tanjungpinang
}

\author{
Level of Aquatic Trophic in the Waters of Kampong Madong, Kampung Bugis Village, \\ Tanjungpinang City
}

\section{Ismail $^{\circledR}$, Winny Retna Melani ${ }^{1}$, Tri Apriadi ${ }^{1}$}

${ }^{1}$ Manajemen Sumberdaya Perairan, Fakultas Ilmu Kelautan dan Perikanan, Universitas Maritim Raja Ali Haji, Tanjungpinang, Indonesia 29111

\section{$\square$ Info Artikel:}

Diterima: 1 Agustus 2018

Revisi: 15 Agustus 2018

Disetujui: 20 Oktober 2018

Dipublikasi: 30 November 2018

\section{[1] Keyword:}

Trophic level, Aquatic Trophic, TRIX, Trophic Index, Perairan Kampung Madung

\section{$\triangle$ Penulis Korespondensi:}

Ismail

Manajemen Sumberdaya Perairan, Fakultas IImu Kelautan dan Perikanan, Universitas Maritim Raja Ali Haji, Tanjungpinang, Indonesia 29111 Email: ismailcoyy@gmail.com

\begin{abstract}
ABSTRAK. Tujuan dari penelitian ini adalah untuk mengetahui tingkat kesuburan perairan berdasarkan indeks TRIX (Trophic Index), serta kondisi perairan fisika, kimia dan biologi di Perairan Kampung Madong Kelurahan Kampung Bugis Kota Tanjungpinang. Penelitian ini dilakukan dengan metode survei sebanyak 15 titik sampling pada saat surut dan 15 titik sampling pada saat pasang pada titik koordinat yang sama. Hasil penelitian ini menunjukkan kualitas perairan Kampung Madong baik parameter fisika maupun kimia pada saat pasang dan surut masih berada pada kriteria sesuai menurut KEPMEN LH No. 51 Tahun 2004 tentang baku mutu air laut untuk biota, namun untuk parameter Nitrat dan Fosfat tidak memenuhi baku mutu. Nilai tingkat kesuburan Perairan Kampung Madong berdasarkan nilai indeks TRIX yaitu pada saat pasang terdapat nilai 4,74 yang tergolong sedang (mesotrofik), sedangkan tingkat kesuburan di Perairan Kampung Madong pada saat surut terdapat nilai indeks TRIX 5,18 yang tergolong tinggi (eutrofik).
\end{abstract}

ABSTRACT. The purpose of this study is to determine the level of water fertility based on the TRIX index (Trophic Index), as well as physical, chemical, and biological water conditions in Kampung Madong Waters, Kampung Bugis Village, Tanjung Pinang City. This research was conducted with a survey method of 15 sampling points at low tide and 15 sampling points at high tide at the same coordinate point. The results of this study indicate the quality of Madong Village Waters both physical and chemical parameters at high tide and low tide are still following the criteria according to KEPMEN LH No. 51 of 2004 concerning seawater quality standards for biota, but for the parameters, Nitrate and Phosphate do not meet quality standards. The fertility rate of Madong Village Waters based on the TRIX index value is that at tide there is a value of 4.74 which is classified as medium (mesotrophic), while the fertility level in Madong Village Waters on the blush there is a TRIX index value of 5.18. which is classified as high (eutrophic).

筫 How to cite this article:

Ismail, Melani, W.R., \& Apriadi, T. (2018). Tingkat Kesuburan Perairan di Perairan Kampung Madong, Kelurahan Kampung Bugis, Kota Tanjungpinang. Jurnal Akuatiklestari, 2(1): 9-13. https://doi.org/10.31629/akuatiklestari.v2i1.931

\section{PENDAHULUAN}

Provinsi Kepulauan Riau merupakan salah satu provinsi di Indonesia yang memiliki luas laut lebih luas dari pada daratan yaitu 96\% lautan dan 4\% daratan, sehingga Kepulauan Riau memiliki potensi sumberdaya alam yang cukup untuk meningkatkan kehidupan dan kesejahteraan masyarakat khususnya masyarakat pesisir. Kabupaten Bintan merupakan kabupaten yang ada di Provinsi Kepulauan Riau yang menjadi Kawasan Konservasi Perairan Daerah (KKPD) sesuai Surat Keputusan Bupati Bintan Nomor 36/VIII/2007, dengan luas wilayah 472.905 hektar (BAPPEDA KEPRI, 2005).

Salah satunya daerah yang berada di Kota Tanjungpinang yang masih memanfaatkan hasil laut sebagai mata pencaharian adalah Kampung Madong, Kelurahan Kampung Bugis yang berada di wilayah administrasi Kota Tanjungpinang Provinsi Kepulauan Riau. Kampung Madong memiliki beberapa ekosistem diantaranya ekosistem mangrove dan lamun. Masyarakat Kampung Madong masih memanfaatkan sumber pencarian dari hasil laut, seperti melakukan penangkapan ikan dan membudidayakan ikan dengan keramba jaring apung.

Perairan ini juga dimanfaatkan untuk berbagai macam aktivitas manusia antara lain kegiatan budidaya ikan dikeramba jaring apung, jalur pompong nelayan, restoran dan pemukiman. Dengan adanya aktivitas masyarakat di Kampung Madong maka akan berpotensi menghasilkan limbah organik yang langsung masuk keperairan dan akhirnya akan merubah kualitas air yang berdampak pada kesuburan perairan tersebut. 
Mengingat adanya kegiatan aktivitas masyarakat yang dilakukan di perairan Kampung Madong, maka perlu dilakukan penelitian mengenai tingkat kesuburan perairan tersebut karena belum pernah dilakukan untuk itu peneliti ingin mengetahui tingkat kesuburan perairan yang berada di Kampung Madong.

\section{BAHAN DAN METODE}

\subsection{Waktu dan tempat}

Penelitian ini dilaksanakan pada bulan Maret - Juni 2018, berlokasi di Perairan Kampung Madong, Kelurahan Kampung Bugis, Kota Tanjungpinang (Gambar 1). Analisis Konsentrasi sampel nitrat dan fosfat dilakukan di laboratorium Badan Teknik Kesehatan Lingkungan Pengendalian Penyakit Kelas Satu Batam dan di Laboratorium Penguji Balai Perikanan Budidaya Laut Batam, sedangkan untuk analisis konsentrasi klorofil-a dilakukan di Laboratorium Fakultas Ilmu Kelautan dan Perikanan Universitas Maritim Raja Ali Haji.

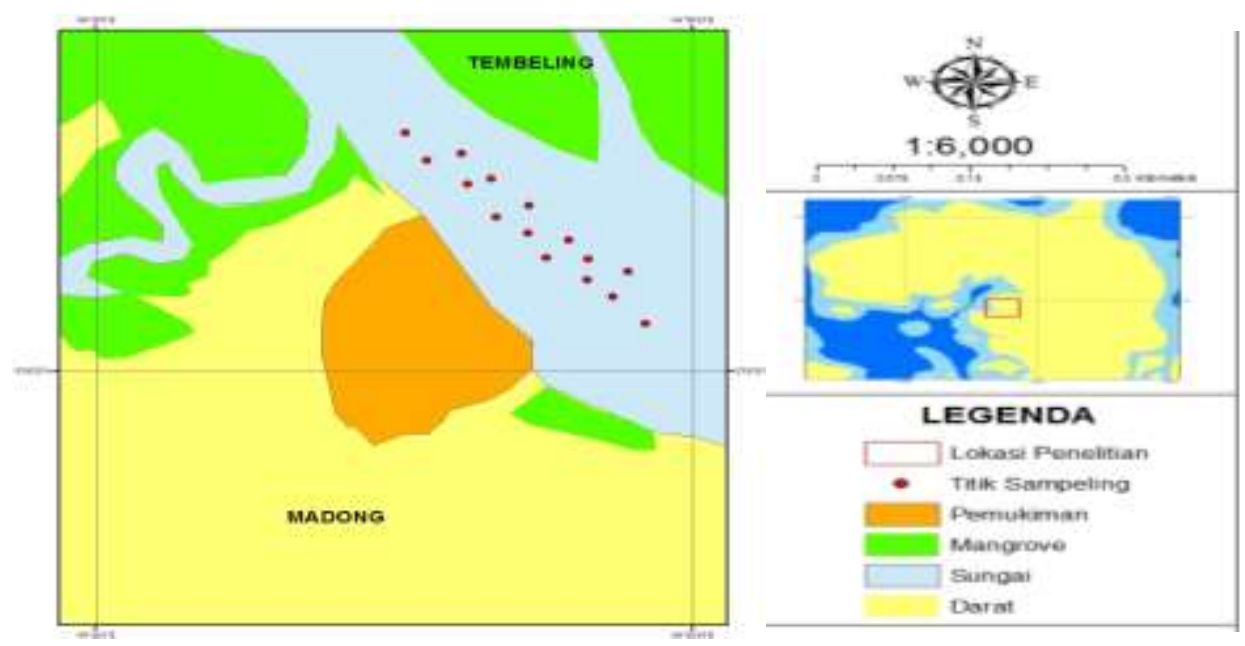

Gambar 1. Peta lokasi penelitian

\subsection{Alat dan Bahan}

Adapun alat dan bahan yang digunakan dalam penelitian dibagi menjadi dua kelompok yaitu di lapangan dan alat yang digunakan di laboratorium. Alat dan bahan yang digunakan di lapangan diantaranya Van dorn Water Sampler 3 liter untuk mengambil sampel air, GPS untuk menentukan posisi titik sampling, botol sampel untuk menyimpan sampel air, ice box untuk wadah penyimpanan sampel air sebelum dianalisis, refractometer untuk mengukur salinitas, Water Multitester untuk mengukur $\mathrm{pH}$, suhu dan DO, layangan arus untuk mengukur kecepatan arus, stopwatch untuk mengukur waktu, secchi disk untuk mengukur kecerahan, perahu/sampan untuk transportasi pengambilan sampel, alat tulis dan kamera digital untuk mencatat keterangan sampel dan dokumentasi, tisu dan aquades untuk membersihkan dan mengeringkan alat, serta alumunium foil dan plastik hitam untuk Membungkus botol sampel klorofil-a, fosfat dan nitrat.

Alat dan bahan yang digunakan di laboratorium antara lain Centrifuger 5430 Eppendrof untuk mengendapkan kertas saring, spatula untuk menghancurkan kertas saring, Spektrofotometer untuk mengukur biomassa klorofil-a dan konsentrasi fosfat, kalorimeter untuk mengukur konsentrasi nitrat, peralatan glass (tabung reaksi, pipet ,dll) untuk membantu proses analisis klorofil-a, sampel air untuk analisis Klorofil-a, nitrat dan fosfat, serta kertas milipore 0,45 mm untuk menyaring air sampel.

\subsection{Prosedur Penelitian}

Penentuan titik sampling dalam penelitian ini menggunakan metode random sampling atau metode acak yaitu pengambilan sampel acak sederhana yang digunakan untuk memilih sampel dari populasi sehingga setiap anggota populasi mempunyai peluang yang sama besar untuk diambil sebagai sampel. Pengambilan sampel diambil sebanyak 15 titik pengamatan. Masing-masing titik terdiri dari 2 kali pengambilan sampel pada saat surut dan pasang.

\subsection{Teknik Pengumpulan Data}

Tingkat kesuburan suatu perairan menggunakan metode TRIX atau trophic index menurut Vollenweider et al. (1998). Metode ini dapat menggambarkan tingkat kesuburan suatu perairan dengan menggunakan empat variabel yaitu klorofila, oksigen terlarut jenuh (DO saturasi), mineral nitrogen (nitrat) dan fosfor (ortofosfat) (Vollenweider et al.,1998). Analisis nitrat dan fosfat dilakukan di laboratorium Badan Teknik Kesehatan Lingkungan Pengendalian Penyakit Kelas Satu Batam dan Laboratorium Penguji Balai Perikanan Budidaya Laut Batam. sedangkan analisis klorofil-a di dilakukan 
di Laboratoriun Marine Biology, Fakultas Ilmu Kelautan dan Perikanan UMRAH. Untuk pengukuran DO dilakukan secara langsung di lapangan dengan menggunakan multitester.

\subsection{Analisis Data}

Perhitungan trophic index (TRIX) dengan rumus sebagai berikut :

$$
T R I X=\frac{k}{n} \sum_{i}^{n} \frac{(\log M-\log L)}{(\log U-\log L)}
$$

Keterangan :

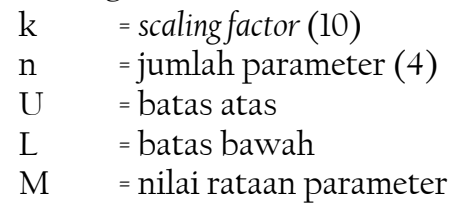

Menurut Amalia (2010), Scaling factor merupakan ukuran kesuburan (trofik) 0 sampai 10 yang menunjukan semakin besar nilai indeks maka semakin tinggi tingkat eutrofikasi pada perairan tersebut. Setelah seluruh nilai parameter didapatkan maka dimasukkan kedalam rumusan perhitungan TRIX, dan disesuaikan dengan klasifikasi indeks kesuburan pada Tabel 1 .

Tabel 1. Penggolongan Rentang Nilai TRIX

\begin{tabular}{ccc} 
Skala TRIX & Status Kualitas Air & Tingkat Eutrofikasi \\
$0,0-4,0$ & Oligotrofik & Rendah \\
$4,1-5,0$ & Mesotrofik & Sedang \\
$5,1-6,0$ & Eutrofik & Tinggi \\
$6,1-10,0$ & Hipertrofik & Sangat Tinggi \\
\hline
\end{tabular}

Sumber : Alves et al. (2013)

\section{HASIL DAN PEMBAHASAN}

\subsection{Kondisi Lingkungan Perairan Kampung Madong}

Pengukuran kualitas air di Perairain Kampung Madong pada saat pasang dan surut yang diambil pada surut terendah dan menuju pasang didapatkan data hasil pengukuran yang bisa dilihat pada Tabel 2.

Tabel 2. Hasil Pengukuran Parameter Fisika, Kimia dan Biologi di Perairan Kampung Madong

\begin{tabular}{|c|c|c|c|c|}
\hline \multirow{2}{*}{ Parameter } & \multirow{2}{*}{ Satuan } & \multicolumn{2}{|c|}{ Rata-rata Hasil Pengukuran } & \multirow{2}{*}{ Baku Mutu* } \\
\hline & & Pasang & Surut & \\
\hline \multicolumn{5}{|l|}{ Fisika } \\
\hline Suhu & ${ }^{\circ} \mathrm{C}$ & $29,17 \pm 0,18$ & $28,8 \pm 0,33$ & Alami \\
\hline Kecerahan & $\mathrm{m}$ & $2,39 \pm 0,15$ & $1,47 \pm 0,17$ & Lamun $>3$ \\
\hline Kecepatan Arus & $\mathrm{m} / \mathrm{s}$ & $0,05 \pm 0,01$ & $0,06 \pm 0,01$ & - \\
\hline \multicolumn{5}{|l|}{ Kimia } \\
\hline Salinitas & $\%$ & $23,07 \pm 1,10$ & $22,73 \pm 1,33$ & Alami \\
\hline Oksigen Terlarut (DO) & $\mathrm{mg} / \mathrm{L}$ & $6,75 \pm 0,30$ & $6,69 \pm 0,329$ & $>5$ \\
\hline Derajat Keasaman(pH) & & $7,38 \pm 0,07$ & $7,13 \pm 0,08$ & $7-8,5$ \\
\hline Nitrat $\left(\mathrm{NO}_{3}\right)$ & $\mathrm{mg} / \mathrm{L}$ & $0,4327 \pm 0,066$ & $0,4333 \pm 0,196$ & 0,008 \\
\hline Fosfat $\left(\mathrm{PO}_{4}\right)$ & $\mathrm{mg} / \mathrm{L}$ & $0,020 \pm 0,007$ & $0,104 \pm 0,202$ & 0,015 \\
\hline \multicolumn{5}{|l|}{ Biologi } \\
\hline Klorofil-a & $\mathrm{mg} / \mathrm{L}$ & $3,49 \pm 1,36$ & $4,87 \pm 1,65$ & \\
\hline
\end{tabular}

Hasil pengukuran parameter suhu, kecerahan, kecepatan arus, salinitas, DO, dan pH pada saat pasang dan surut memenuhi baku mutu berdasarkan KepMen LH NO. 51 Tahun 2004. Suhu di perairan kampung madong tergolong dalam keadaan normal untuk kehidupan biota khususnya ikan-ikan. Ikan dapat mengalami stres apabila suhu yang tidak normal, suhu merupakan faktor penting dalam kesuburan dan keseimbangan kualitas perairan. Tingkat kecerahan perairan sangat dipengaruhi oleh padatan tersuspensi yang berasal dari darat dan di dalam perairan, semakin jauh dari daratan padatan tersuspensi semakin rendah dan penetrasi cahaya semakin tinggi yang dapat menembus kedasar perairan sehingga tingkat kecerahan semakin tinggi dan sebaliknya (Nuriya et al., 2010). 
Menurut Nontji (2007), arus merupakan gerakan mengalir suatu massa air yang dapat disebabkan oleh tiupan angin, karena perbedaan dalam densitas air laut atau disebabkan oleh gerakan gelombang. Arus juga berperan penting dalam kesuburan perairan apabila arus yang tinggi maka akan mengakibatkan unsur hara yang tidak optimum bagi periaran tersebut sehingga akan kurang bila ditinjau dari kesuburan perairan (Haryoko et al., 2018).

Menurut Rukminasari et al. (2014), peningkatan salinitas dapat terjadi karena penguapan air yang mengurangi volume air sehingga konsentrasi garam-garam terlarut di dalamnya meningkat bahwa fluktuasi salinitas dipengaruhi oleh beberapa faktor yaitu besar kecilnya penguapan air, pencampuran oleh air lain dimana berbeda salinitasnya dan adanya pengendapan. Salinitas pada saat surut lebih rendah dibandingkan pada saat pasang. Hal ini dikarenakan massa air laut yang masuk ke badan perairan lebih sedikit sehingga menyebabkan rendahnya kadar salinitas. Sebaran salinitas dipengaruhi oleh berbagai faktor seperti pola sirkulasi air, penguapan (evaporasi), curah hujan (presipitasi), dan aliran sungai (run off) yang ada disekitarnya (Nontji. 2007).

Menurut Salmin (2005), kadar oksigen dalam air laut bertambah dengan semakin rendahnya suhu dan berkurang dengan semakin tinggi salinitas. Pada lapisan permukaan, kadar oksigen akan lebih tinggi, karena adanya proses difusi antara air dengan udara bebas serta adanya proses fotosintesis.

Menurut Susana (2009), air laut umumnya memiliki nilai pH di atas 7 yang berarti bersifat basa, namun dalam kondisi tertentu nilainya dapat menjadi lebih rendah dari 7 sehingga menjadi bersifat asam. Sebagian besar biota akuatik sensitif terhadap perubahan nilai $\mathrm{pH}$, nilai yang ideal untuk kehidupan antara $7-8,5$. Pada nilai $\mathrm{pH}$ yang lebih rendah (44), sebagian besar tumbuhan air mati karena tidak dapat bertoleransi terhadap pH rendah. Menurut Rigitta et al. (2015), semakin ke wilayah lepas laut kadar nitrat semakin rendah. konsentrasi nitrat menunjukan bahwa tingkat kesuburan perairan Kampung Madong berdasarkan kadar nitrat pada saat pasang maupun surut berada dalam tingkatan oligotrofik, yaitu dalam tingkat rendah.

Menurut Mustofa (2015), berdasarkan kategori tingkat kesuburan perairan Kampung Madong kadar fosfat pada saat pasang berada dalam tingkat kesuburan sedang, yaitu dalam tingkat mesotrofik. Sedangkan pada saat surut berada dalam tingkat kesuburan tinggi, yaitu dalam tingkat eutrofik.

Tingginya nilai klorofil-a pada saat surut, diduga karena adanya pasokan nutrien dari darat yang masuk ke badan perairan. Kandungan nutrien yang tinggi di perairan akan dimanfaatkan oleh fitoplankton untuk tumbuh dan berkembang biak. fitoplankton dikenal sebagai tumbuhan yang mengandung pigmen klorofil sehingga mampu melakukan reaksi fotosintesis. Tinggi rendahnya kandungan klorofil-a dipengaruhi oleh faktor hidrologi perairan yaitu, suhu, salinitas, pH, DO, arus, nitrat dan fosfat (Sihombing et al., 2013). Rendahnya nilai klorofil-a pada saat pasang diduga karena tidak ada masukan nutrien dari daratan secara langsung. Secara horizontal kandungan klorofil-a lebih banyak ditemukan pada lapisan permukaan yang berada dekat dengan daratan dimana semakin menuju laut maka kandungan klorofil-a semakin rendah karena daratan banyak memberi masukan nutien kedalam perairan.

\subsection{Tingkat Kesuburan Perairan Kampung Madong}

Hasil perhitungan tingkat kesuburan perairan berdasarkan indeks TRIX pada saat pasang dan surut di Perairan Kampung Madong, dapat dilihat pada Gambar 2.

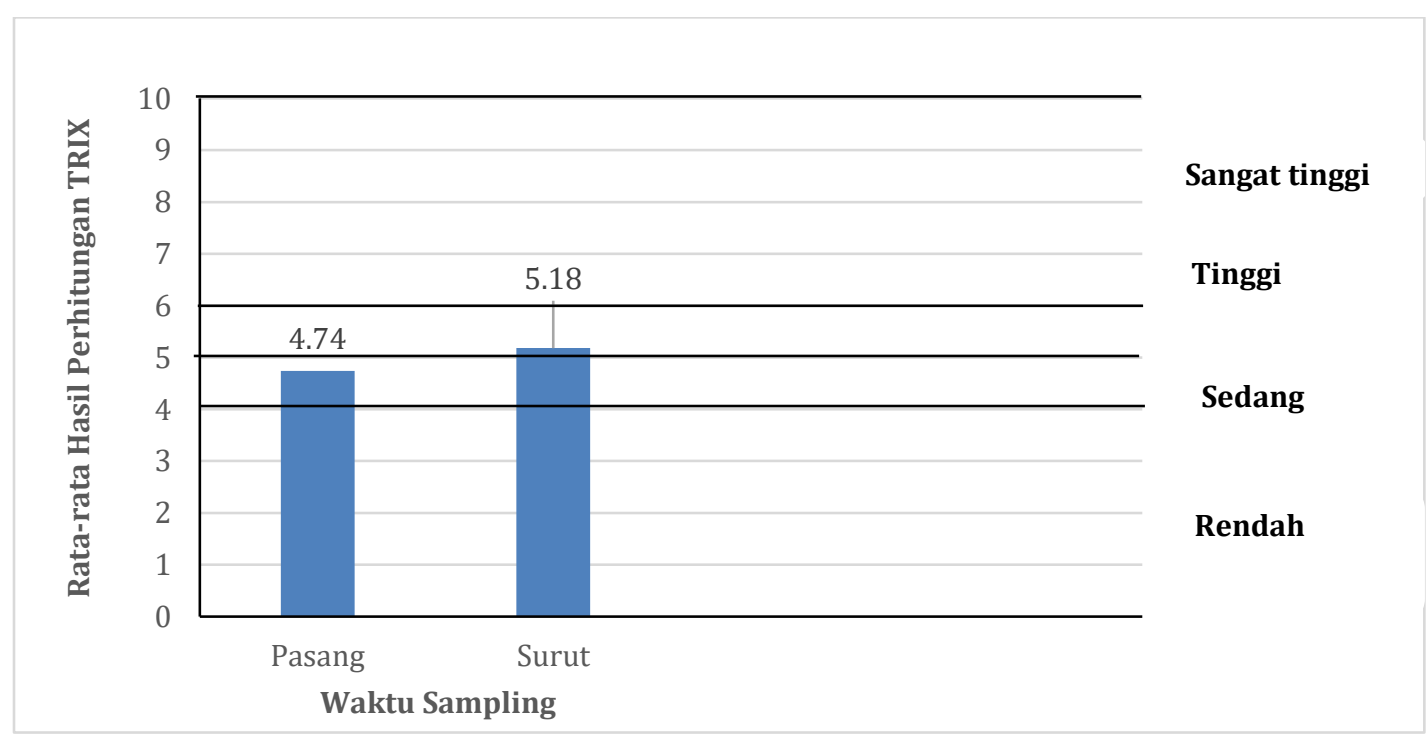

Gambar 2. Tingkat Kesuburan berdasarkan TRIX

Hasil pengukuran tingkat kesuburan perairan Kampung Madong pada saat pasang tergolong mesotrofik atau tingkat kesuburan sedang. Hal ini disebabkan oleh rendahnya parameter penunjang tingkat kesuburan seperti nitrat, fosfat, klorofil-a, DO saturasi dan salinitas yang di dapatkan di lokasi penelitian pada saat pasang. Rendahnya parameter penunjang tingkat kesuburan perairan akan berpengaruh juga pada tingkat kesuburan, sedangkan pada saat surut tingkat kesuburan perairan Kampung Madong tergolong eutrofik atau tingkat kesuburan tinggi. Hal ini disebabkan 
tinggi nya parameter penunjang perairan pada saat surut sehingga berdampak tingginya tingkat kesuburan perairan pada saat surut.

Menurut Naila et al. (2013), tingkat kesuburan tinggi disebabkan oleh meningkatnya kandungan nutrien pada wilayah perairan tersebut, selain itu peningkatan unsur hara juga dapat disebabkan oleh adanya sisa pakan dan sisa metabolisme ikan budidaya yang masuk ke perairan. Hal ini juga dinyatakn oleh Patty et al. (2015), bahwa eutrofikasi merupakan pengkayaan unsur hara (nutrien) terutama nitrat dan fosfat yang ditandai dengan terjadinya blooming fitoplankton dan menyebabkan kematian berbagai jenis biota laut dan bahkan bisa menyebabkan pencemaran dan menurunnya kualitas perairan.

Berdasarkan penggolongan rentang nilai TRIX tingkat kesuburan perairan Kampung Madong pada saat surut tergolong eutrofik atau tingkat kesuburan tinggi, sedangkan pada saat pasang tingkat kesuburan perairan tergolong mesotrofik atau tingkat kesuburan sedang (Alves et al., 2013).

\section{SIMPULAN}

Berdasarkan hasil penelitian yang dilakukan dapat disimpulkan bahwa Perairan Kampung Madong baik fisika maupun kimia pada saat pasang dan surut masih berada pada kriteria sesuai menurut KepMen LH No. 51 Tahun 2004 tentang baku mutu air laut untuk biota air laut. Namun untuk parameter nitrat dan fosfat tidak memenuhi kriteria diatas ambang baku mutu. Tingkat kesuburan Perairan Kampung Madong berdasarkan nilai indeks TRIX yaitu pada saat pasang tergolong sedang (mesotrofik), sedangkan tingkat kesuburan di pPrairan Kampung Madong pada saat surut tergolong tinggi (eutrofik).

\section{UCAPAN TERIMA KASIH}

Terimakasih saya ucapkan kepada kedua orang tua, dosen pembimbing dan teman-teman mahasiswa Manajemen Sumberdaya Perairan angkatan 2014 yang telah membantu saya dalam menyelesaikan penelitian ini.

\section{REFERENSI}

Alves, G., Flores-montes, M., Gaspar, F., \& Gomes, J. (2013). Eutrophication and Water Quality In A Tropical Brazilian Estuary. Journal of Coastal Research, 65: 7-12.

Amalia, F. J. (2010). Pendugaan Status Kesuburan Perairan Danau Lido, Bogor, Jawa Barat, Melalui Beberapa Pendekatan. Institut Pertanian Bogor. BABPPEDA. (2005). Rencana Pembangunan Jangka Panjang (RPJP) Provinsi Kepri 2005-2025. Provinsi Kepulauan Riau.

Haryoko, I., Melani, W. R., \& Apriadi, T. (2018). Eksistensi Bacillariophyceae dan Chlorophyceae di Perairan Sei Timun Kota Tanjungpinang, Kepulauan Riau. Jurnal Akuatiklestari, 1(2), 1-7.

Keputusan Menteri Negara Lingkungan Hidup Nomor: 51 Tahun 2004 tentang Baku Mutu Air Laut Biota.

Mustofa, A. (2015). Kandungan Nitrat dan Fosfat Sebagai Faktor Tingkat Kesuburan Perairan Pantai. Jurnal DISPROTEK, Fakultas Sains dan Teknologi UNISNU Jepara, 6(1): 13-19.

Naila, Z., \& Aisyah. (2013). Status Trofik Perairan Rawa Peningditinjau Dari Kandungan Unsur Hara (NO3 dan PO4) Serta Klorofila. Bawal, 5(3) : 189-199.

Nontji, A. (2007). Laut Nusantara. Penerbit: Djambatan. Jakarta.

Rigita, T.M.A., Maslukah, L., \& Yusuf, M. (2015). Sebaran Fosfat Dan Nitrat Di Perairan Morodemak, Kabupaten Demak. Journal of Oseanografi, 4(2): 415-422.

Rukminasari, N., Nadiarti, \& Khaerul, A. (2014). Pengaruh Derajat Keasaman pH Air Laut Terhadap Konsentrasi Kalsium dan Laju Pertumbuhan Halimeda sp. Torani (Jurnal Ilmu Kelautan dan Perikanan), 24(1): 28-34.

Salmin. (2005). Oksigen Terlarut (DO) dan Kebutuhan Oksigen Biologi (BOD) sebagai Salah Satu Indikator untuk Menentukan Kualitas Perairan. Oseana, XXX(3): 21-26.

Sihombing, R.F., Aryawati, R., \& Hartoni. (2013). Kandungan Klorofil-a Fitoplankton di Sekitar Perairan Desa Sungsang Kabupaten Banyuasin Provinsi Sumatera Selatan. Maspari, 5(1): 34-39.

Vollenweider, R.A., Giovanardi, F., Montanari, G., \& Rinaldi, A. (1998). Characterization of the trophic conditions ff marine coastal waters with special reference to the nw adriatic sea: proposal for a trophic scale, turbidity and generalized water quality index. Environmetrics, 9(3): 329-357. 